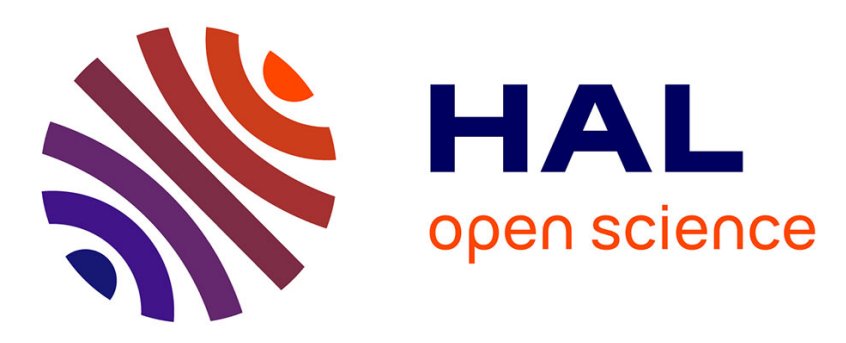

\title{
Intercontinental transport of anthropogenic sulfur dioxide and other pollutants: An infrared remote sensing case study
}

Lieven Clarisse, Michael Fromm, Yasmine Ngadi, Louisa Emmons, Cathy Clerbaux, Daniel Hurtmans, Pierre-François Coheur

\section{To cite this version:}

Lieven Clarisse, Michael Fromm, Yasmine Ngadi, Louisa Emmons, Cathy Clerbaux, et al.. Intercontinental transport of anthropogenic sulfur dioxide and other pollutants: An infrared remote sensing case study. Geophysical Research Letters, 2011, 38 (19), pp.L19806. 10.1029/2011GL048976 . hal00632738

\section{HAL Id: hal-00632738 \\ https://hal.science/hal-00632738}

Submitted on 18 Mar 2016

HAL is a multi-disciplinary open access archive for the deposit and dissemination of scientific research documents, whether they are published or not. The documents may come from teaching and research institutions in France or abroad, or from public or private research centers.
L'archive ouverte pluridisciplinaire HAL, est destinée au dépôt et à la diffusion de documents scientifiques de niveau recherche, publiés ou non, émanant des établissements d'enseignement et de recherche français ou étrangers, des laboratoires publics ou privés. 


\title{
Intercontinental transport of anthropogenic sulfur dioxide and other pollutants: An infrared remote sensing case study
}

\author{
Lieven Clarisse, ${ }^{1}$ Michael Fromm, ${ }^{2}$ Yasmine Ngadi, ${ }^{1}$ Louisa Emmons, ${ }^{3}$ \\ Cathy Clerbaux, ${ }^{1,4}$ Daniel Hurtmans, ${ }^{1}$ and Pierre-François Coheur ${ }^{1}$ \\ Received 21 July 2011; revised 7 September 2011; accepted 13 September 2011; published 13 October 2011.
}

[1] Using 3 years worth of IASI (the Infrared Atmospheric Sounder Interferometer aboard METOP-A) measurements, we have identified 24 major events of uplift and transport of anthropogenic sulfur dioxide. These were all first observed over East Asia, and could be traced for over 60 hours. On 7 November 2010 a sulfur dioxide plume was observed over Northeast China and tracked for five days to North America. We discuss this event in detail with respect to build up; uplift and in-plume chemistry. We found a host of trace gas enhancements in the plume $\left(\mathrm{SO}_{2}, \mathrm{CO}, \mathrm{PAN}, \mathrm{CH}_{3} \mathrm{OH}, \mathrm{HCOOH}\right.$ and $\left.\mathrm{C}_{2} \mathrm{H}_{2}\right)$. A reasonable to very good agreement was found with MOZART-4 modeled ambient columns for all species except methanol, which was underestimated by the model by an order of magnitude. We calculate correlations of the different species and give observational evidence of secondary in-plume formation of methanol and PAN. Citation: Clarisse, L., M. Fromm, Y. Ngadi, L. Emmons, C. Clerbaux, D. Hurtmans, and P.-F. Coheur (2011), Intercontinental transport of anthropogenic sulfur dioxide and other pollutants: An infrared remote sensing case study, Geophys. Res. Lett., 38, L19806, doi:10.1029/2011GL048976.

\section{Introduction}

[2] Transport of pollution has an impact on atmospheric composition, chemistry and air quality across continents from the boundary layer up to stratosphere. Its importance has been established through a large number of model studies and in situ measurements [see, e.g., Liang et al., 2004; Heald et al., 2003; Talbot et al., 2003; Kritz et al., 1990; Chin et al., 2007; Stohl, 2001; Fiedler et al., 2009; Barrie, 1986; Law and Stohl, 2007; Jaffe et al., 1999]. Outflow from East Asia is largely controlled by monsoons and throughout the year reaches North America either via the North Pacific or via the Arctic (mostly in the winter) [Stohl et al., 2002]. Uplift and export mechanisms have a strong seasonal variability with spring being the most favorable period for transpacific transport due to active weather associated with frequent ascending air parcels and

\footnotetext{
${ }^{1}$ Spectroscopie de l'Atmosphère, Service de Chimie Quantique et Photophysique, Université Libre de Bruxelles, Brussels, Belgium.

${ }^{2}$ U.S. Naval Research Laboratory, Washington, DC, USA.

${ }^{3}$ National Center for Atmospheric Research, Boulder, Colorado, USA.

${ }^{4}$ UPMC Université Paris 6, Université Versailles St.-Quentin, CNRS/INSU, LATMOS-IPSL, Paris, France.

Copyright 2011 by the American Geophysical Union. 0094-8276/11/2011GL048976
}

fast moving westerly winds [Liu et al., 2003; Russo et al., 2003].

[3] The IASI infrared sounder [Clerbaux et al., 2009] aboard MetOp-A has twice a day global coverage, which allows detection and analysis of the evolution of atmospheric plumes such as those arising from a volcanic eruption [Clarisse et al., 2008] or biomass burning [Coheur et al., 2009]. Here for the first time we use IASI to study transport of anthropogenic pollution plumes and analyze a particular plume first spotted above East Asia on 7 November 2010. IASI has a good spectral resolution, which permits measurement of a variety of trace gases [Clarisse et al., 2011]. For this event we were able to measure plume enhancements of carbon monoxide (CO), sulfur dioxide $\left(\mathrm{SO}_{2}\right)$, peroxyacetyl nitrate $(\mathrm{PAN})$, formic acid $(\mathrm{HCOOH})$, acetylene $\left(\mathrm{C}_{2} \mathrm{H}_{2}\right)$, methanol $\left(\mathrm{CH}_{3} \mathrm{OH}\right)$ and their evolution in time as the plume diluted and underwent chemistry and washout. It is the first study of this type as satellite studies of Asian anthropogenic outflow have traditionally been focused on CO [Turquety et al., 2008; Zhang et al., 2006] and aerosols [Yu et al., 2008; Di Pierro et al., 2011]. Infrared sounders are generally not sensitive to anthropogenic $\mathrm{SO}_{2}$; and we therefore start section 2 by giving an overview of the frequency and seasonality of such anthropogenic $\mathrm{SO}_{2}$ observations, before describing the event observed in November 2010. In section 3 we give a quantitative analysis of the event for the reported trace species and briefly compare with outputs from the MOZART model.

\section{Anthropogenic $\mathrm{SO}_{2}$ and the November Event}

[4] While UV-vis instruments routinely measure anthropogenic $\mathrm{SO}_{2}$ [Lee et al., 2011], this is not the case for infrared instruments which have limited sensitivity to boundary layer $\mathrm{SO}_{2}$. For the $\nu_{3}$ absorption band of $\mathrm{SO}_{2}$ (which is the strongest absorption band in the infrared) this is due to competing, and dominating water vapor absorption in the same spectral range. When $\mathrm{SO}_{2}$ is observed in this band it must be present in a significant amount at altitudes above the lower troposphere $(5-7 \mathrm{~km}$ depending on the water vapor profile and $\mathrm{SO}_{2}$ concentrations [Clarisse et al., 2008]).

[5] We have analyzed $\mathrm{SO}_{2}$ retrievals for the complete period October 2007-December 2010 in search of anthropogenic emissions of $\mathrm{SO}_{2}$. Because of frequent volcanic activity, especially in the Northern Hemisphere, the produced imagery was analyzed manually and cross checked with volcanic activity reports from the USGS (http://www. 

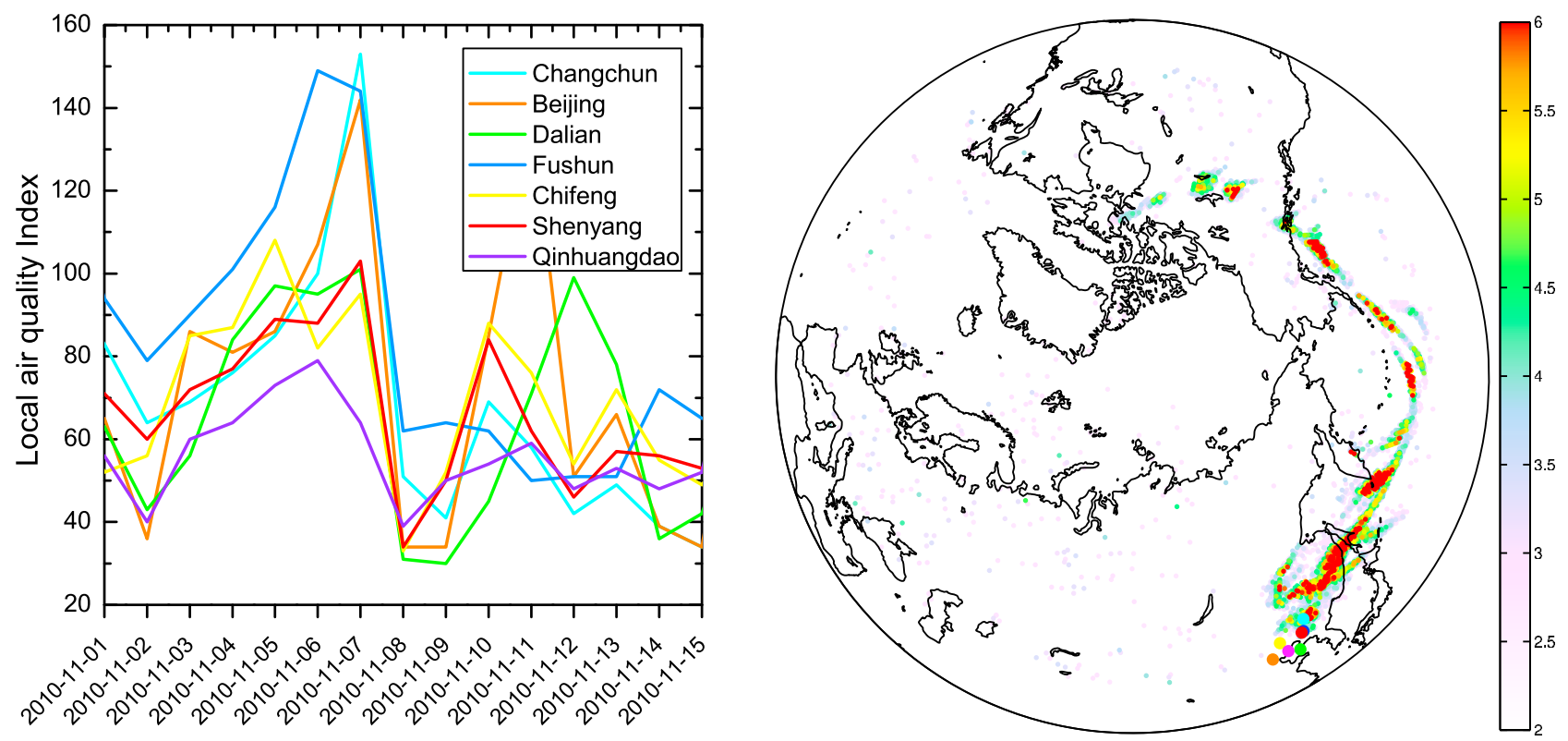

Figure 1. (left) Daily Air Pollution Index from selected cities in China. The air quality decreases from 1 to 7 November and is attributed to build-up of pollution. On the 8th a drastic improvement is apparent, coincident with the IASI observation of the $\mathrm{SO}_{2}$ plume shown on the right. (right) Location of selected cities (colored dots) and maximum observed $\mathrm{SO}_{2}$ columns (in units $10^{16}$ molecules $/ \mathrm{cm}^{2}$ ) for the period 7-11 November 2010 .

volcano.si.edu/reports/usgs/). In total we identified 24 major events where an apparent non-volcanic $\mathrm{SO}_{2}$ plume was observed with loadings above $5 \mathrm{~km}$ exceeding $\sim 510^{16}$ molecules $/ \mathrm{cm}^{2}$ and which was visible for at least 5 consecutive IASI overpasses ( $2 \frac{1}{2}$ days). All these were first observed over East Asia and Siberia; while transport was mainly observed over the Russian Arctic, Japan, Sakhalin and Kamchatka. There is a marked seasonality in the events with 12 events observed in the fall, 9 in the winter and 3 in the spring.

[6] A first prerequisite for such large events to happen and for infrared sounders to see them, is the availability of large concentrations of $\mathrm{SO}_{2}$. Note first that emissions of $\mathrm{SO}_{2}$ only show a weak seasonal pattern [Streets et al., 2003]. In colder periods, the lifetime of $\mathrm{SO}_{2}$ is however longer (a factor 2-3 in winter [Chin and Jacob, 1996; Lee et al., 2011]) because of slower dry deposition and less availability of oxidants. Furthermore, $\mathrm{SO}_{2}$ is half-soluble and subject to wet scavenging. Over East Asia, precipitation has a marked seasonality, with fall and winter being very dry and spring and especially summer very wet. Enhanced with trapping of boundary layer air due to inversion, fall and winter are therefore favorable periods for the build up of large concentrations of $\mathrm{SO}_{2}$. The second prerequisite is an efficient uplift mechanism to altitudes above $5 \mathrm{~km}$. The occurrence of midlatitude cyclones and the associated warm conveyor belts are the main source of uplift to the mid-upper troposphere and occur frequently in fall and winter (note that these occur less frequent in the summer) [Stohl, 2001; Liang et al., 2004; Yienger et al., 2000].

[7] This seasonality is very different as compared to $\mathrm{CO}$, which is known to exhibit most transpacific transport in the spring (and to lesser extent in the summer). This can be seen e.g. from looking at monthly averages of $\mathrm{CO}$ [Clerbaux et al., 2009, Figure 5]. To understand this apparent contradiction, it is important to take into account the seasonality in the number of uplift events, the availability of source material and the altitude of transport. In the work of Liang et al. [2004] it was shown that the number of uplift events does not exhibit a strong seasonality (although the uplift mechanism can be different, e.g. in summer convective lifting is more important). However, in spring and summer, the amount of $\mathrm{CO}$ that is lifted and transported is larger due to larger source availability. Secondly, here we have only taken into account $\mathrm{SO}_{2}$ transport events above $5 \mathrm{~km}$, while the well known seasonality of $\mathrm{CO}$ transport includes transport at all altitude levels. Finally, the number of large uplift events might not be a good indication of the total amount of transported material, for which also a large number of smaller events can contribute.

[8] On 7 November 2010, IASI observed a $\mathrm{SO}_{2}$ plume covering almost the whole of Northeast China and subsequent overpasses show the plume moving over the Sea of Japan, Northern Pacific, Gulf of Alaska and Canada. The last observations was made 5 days later near Hudson bay (see Figure S1 and Animation S1 in the auxiliary material). ${ }^{1}$ Fortuitous overpasses of the space-borne lidar Calipso [Winker et al., 2009] revealed coincident aerosol features between 6 and $9 \mathrm{~km}$ which were identified as smoke and in the later stages as sulfate. For all but the first overpass there was part of the aerosol curtain which contained no detectable clouds, and these were selected for Figure S1 in the auxiliary material.

[9] In terms of meteorology, the week prior the event was characterized by low surface winds and a total absence of rain. These stagnant conditions led to build up of pollutants as reflected in the steady increase of the Daily Air Pollution Index [Gao et al., 2011] of several megacities in Northeast China during that week (see Figure 1, left). Weather maps of

\footnotetext{
${ }^{1}$ Auxiliary materials are available in the HTML. doi:10.1029/ 2011 GL048976.
} 
Table 1. Overview of the event ${ }^{\mathrm{a}}$

\begin{tabular}{lcccccccc}
\hline Day & Clouds (\%) & Size $\left(\mathrm{km}^{2}\right)$ & $\mathrm{CH}_{3} \mathrm{OH}$ & $\mathrm{HCOOH}$ & $\mathrm{CO}$ & $\mathrm{SO}_{2}$ & $\mathrm{PAN}_{2}$ \\
\hline $07 \mathrm{AM}$ & - & - & $0.30 \mathrm{e} 16$ & $0.55 \mathrm{e} 16$ & $2.00 \mathrm{e} 18$ & $5.00 \mathrm{e} 16(25)$ & $0.40 \mathrm{e} 16(1.5)$ & $0.75 \mathrm{e} 16(3.0)$ \\
$07 \mathrm{PM}$ & 73 & $0.6 \mathrm{e} 6$ & $3.17 \mathrm{e} 16$ & $1.00 \mathrm{e} 16$ & $1.65 \mathrm{e} 18$ & $5.93 \mathrm{e} 16(25)$ & $0.75 \mathrm{e} 16(3.8)$ & $1.00 \mathrm{e} 16(4.7)$ \\
$08 \mathrm{AM}$ & 61 & $1.0 \mathrm{e} 6$ & $3.91 \mathrm{e} 16$ & $1.25 \mathrm{e} 16$ & $1.80 \mathrm{e} 18$ & $6.27 \mathrm{e} 16(21)$ & $1.04 \mathrm{e} 16(3.6)$ & $1.05 \mathrm{e} 16(4.3)$ \\
$08 \mathrm{PM}$ & 47 & $1.4 \mathrm{e} 6$ & $4.04 \mathrm{e} 16$ & $1.55 \mathrm{e} 16$ & $2.01 \mathrm{e} 18$ & $6.46 \mathrm{e} 16(26)$ & $1.69 \mathrm{e} 16(4.0)$ & $1.12 \mathrm{e} 16(4.1)$ \\
$09 \mathrm{AM}$ & 34 & $1.6 \mathrm{e} 6$ & $3.42 \mathrm{e} 16$ & $1.26 \mathrm{e} 16$ & $1.58 \mathrm{e} 18$ & $5.42 \mathrm{e} 16(25)$ & $1.13 \mathrm{e} 16(4.7)$ & $0.82 \mathrm{e} 16(3.1)$ \\
$09 \mathrm{PM}$ & 36 & $1.1 \mathrm{e} 6$ & $3.16 \mathrm{e} 16$ & $1.20 \mathrm{e} 16$ & $1.58 \mathrm{e} 18$ & $5.17 \mathrm{e} 16(24)$ & $1.05 \mathrm{e} 16(3.6)$ & $0.80 \mathrm{e} 16(2.6)$ \\
$10 \mathrm{AM}$ & 36 & $1.1 \mathrm{e} 6$ & $3.20 \mathrm{e} 16$ & $1.03 \mathrm{e} 16$ & $1.21 \mathrm{e} 18$ & $4.87 \mathrm{e} 16(26)$ & $0.81 \mathrm{e} 16(3.7)$ & $0.64 \mathrm{e} 16(3.1)$ \\
$10 \mathrm{PM}$ & 17 & $0.7 \mathrm{e} 6$ & $2.84 \mathrm{e} 16$ & $0.99 \mathrm{e} 16$ & $1.23 \mathrm{e} 18$ & $4.55 \mathrm{e} 16(28)$ & $0.63 \mathrm{e} 16(3.1)$ & $0.72 \mathrm{e} 16(2.4)$ \\
$11 \mathrm{AM}$ & 7 & $0.4 \mathrm{e} 6$ & $2.74 \mathrm{e} 16$ & $0.94 \mathrm{e} 16$ & $0.70 \mathrm{e} 18$ & $4.00 \mathrm{e} 16(22)$ & $0.48 \mathrm{e} 16(2.8)$ & $0.57 \mathrm{e} 16(2.7)$ \\
$11 \mathrm{PM}$ & 8 & $0.3 \mathrm{e} 6$ & $2.69 \mathrm{e} 16$ & $0.76 \mathrm{e} 16$ & $0.92 \mathrm{e} 18$ & $3.59 \mathrm{e} 16(29)$ & $0.38 \mathrm{e} 16(0.8)$ & $0.49 \mathrm{e} 16(2.3)$ \\
\hline
\end{tabular}

${ }^{a}$ First column is the date (in November 2010); and the overpass (morning or evening). The second column is the average cloud coverage from the IASI level 2 data. The third column is the size of the plume as estimated from the $\mathrm{SO}_{2}$ retrievals. The remaining columns are maximum observed column enhancements (averaging the 10 highest observations) in molecules $/ \mathrm{cm}^{2}$. For the species which correlate well with CO the enhancement ratio or slope $\Delta \mathrm{X} / \Delta \mathrm{CO}$ is shown in brackets in units of $10^{-3}$. The first line (07AM) represent maximum MOZART4 modeled columns below $800 \mathrm{hPa}$ over the likely source area prior to the event.

the 6th and the 7th November show an intensifying baroclinic cyclone over Northeast China and Korea forming thick clouds and accompanying rain further northeast of this area. The associated warm conveyor belt is no doubt responsible for the lofting and entraining of the local pollutants picked up by IASI. Note that associated cloud formation is important because of potential washout of pollutants and the remote sensing challenge of dealing with optical thick clouds. These can hamper the retrieval and, as we will see further, bias it low.

\section{Composition, Columns and Comparisons}

[10] Comparison of $\mathrm{SO}_{2}$ data with near real time $\mathrm{CO}$ retrievals [George et al., 2009] reveal coincident enhancements. To assess enhancements of other species in the plume, differences of averaged spectra inside the plume (using spectra with $\mathrm{SO}_{2}$ columns above $\sim 510^{16}$ molecules $/ \mathrm{cm}^{2}$ ) and outside the plume (spectra with no detectable $\mathrm{SO}_{2}$ ) were made. This technique allows detection of weak absorbers, as it reduces noise and removes a large part of the spectral signatures due to the strong absorbers $\left(\mathrm{CO}_{2}, \mathrm{O}_{3}, \mathrm{H}_{2} \mathrm{O}\right.$ [Karagulian et al., 2010]). Unambiguous identification of $\mathrm{CO}(3 \mathrm{~K}), \mathrm{PAN}(0.4 \mathrm{~K}), \mathrm{HCOOH}(0.5 \mathrm{~K}), \mathrm{C}_{2} \mathrm{H}_{2}(1 \mathrm{~K})$, $\mathrm{CH}_{3} \mathrm{OH}(0.4 \mathrm{~K})$ was possible for each overpass. Here the numbers in brackets are averaged observed signal strengths and these emerge well above the IASI noise $(\sim 0.2 \mathrm{~K}$ on an individual spectrum).

[11] For all detected species, we have performed optimal estimation retrievals using Atmosphit [Coheur et al., 2005, 2009], limiting the retrieval of the target species between 6 and $9 \mathrm{~km}$ (except for $\mathrm{CO}$ which was fitted from 0 to $15 \mathrm{~km}$ ). Cloudy scenes are problematic since clouds are not directly taken into account by Atmosphit. Thin clouds or small cloud fractions can be compensated by a correction in surface temperature, but thick clouds distort the baseline shape and lead to diverging fits. For this reason we have performed optimal estimation retrievals only for spectra with a cloud coverage below $10 \%$. Unfortunately, especially for the first overpasses, the cloud fraction was very high $(73 \%$ clouds on average for the first overpass, see Table 1), resulting in only few retrievals, mostly on the plume edge (and thus missing the highest loadings). Recently, Walker et al. [2011] introduced a method of detecting weakly absorbing species yielding an apparent column amount. For fixed atmospheric conditions and far away from saturation, the apparent col- umn is linearly related with the true column amount. We have implemented the detection using the so-called ensemble method from Walker et al. [2011] and confirmed a strong linear correlation (between 0.75 and 0.95 ) between apparent and observed columns. This was used to obtain true column amounts for all pixels in and around the observed $\mathrm{SO}_{2}$ plume. This method does not work for $\mathrm{CO}$, which is a strong absorber with a saturating spectral signature and omnipresent in the atmosphere.

[12] The retrievals obtained in this way are illustrated for $\mathrm{SO}_{2}, \mathrm{HCOOH}, \mathrm{C}_{2} \mathrm{H}_{2}$ and PAN in Figure 2 and summarized in Table 1, which contains maximum measured columns (mean of the largest ten observations). For CO, mean outof-plume columns were subtracted from the total columns and as the other species were not detected outside the plume we can interpret all columns as in-plume enhancements. For all species maximum loadings were detected on the third overpass (evening overpass of the 8 th), indicating underestimated loadings for the first two overpasses due to cloud coverage.

[13] By inter-comparing the different species, more can be said on the in-plume chemistry and lifetime. $\mathrm{CO}$ and $\mathrm{C}_{2} \mathrm{H}_{2}$ abundances are usually correlated in the atmosphere [Xiao et al., 2007]. Because of difference in lifetime, the ratio $\mathrm{C}_{2} \mathrm{H}_{2} / \mathrm{CO}$ or enhancement ratio $\Delta \mathrm{C}_{2} \mathrm{H}_{2} / \Delta \mathrm{CO}$ can be used as a tracer of air mass age. We found an average correlation coefficient of 0.59 . The initial value for the enhancement ratio was found to be $4.710^{-3}$, with the slope declining to $2.310^{-3}$ for the aged plume. These values were obtained from linear regression of all measurements in the plume. The initial value matches closely the reported emission average of $4.810^{-3}$ [Xiao et al., 2007] for East Asia.

[14] The best correlation with $\mathrm{CO}$ was found with PAN with an average correlation coefficient of 0.68 . PAN production peaks in the summer, however photochemical production of PAN can also be elevated outside the summer and thermal stability at lower temperatures can account for increased concentrations [Brice et al., 1988; Tsalkani et al., 1987]. Its enhancement ratio with CO was initially $\sim 3.710^{-3}$, increased to $\sim 4.710^{-3}$ and then dropped the last day to $\sim 0.810^{-3}$. On the third overpass remarkably high columns were measured (more than a factor two of what was observed during the first overpass). This increase is much larger than any of the other species, and therefore unlikely related to the cloud retrieval problem. It is indicative of secondary formation within the plume. 

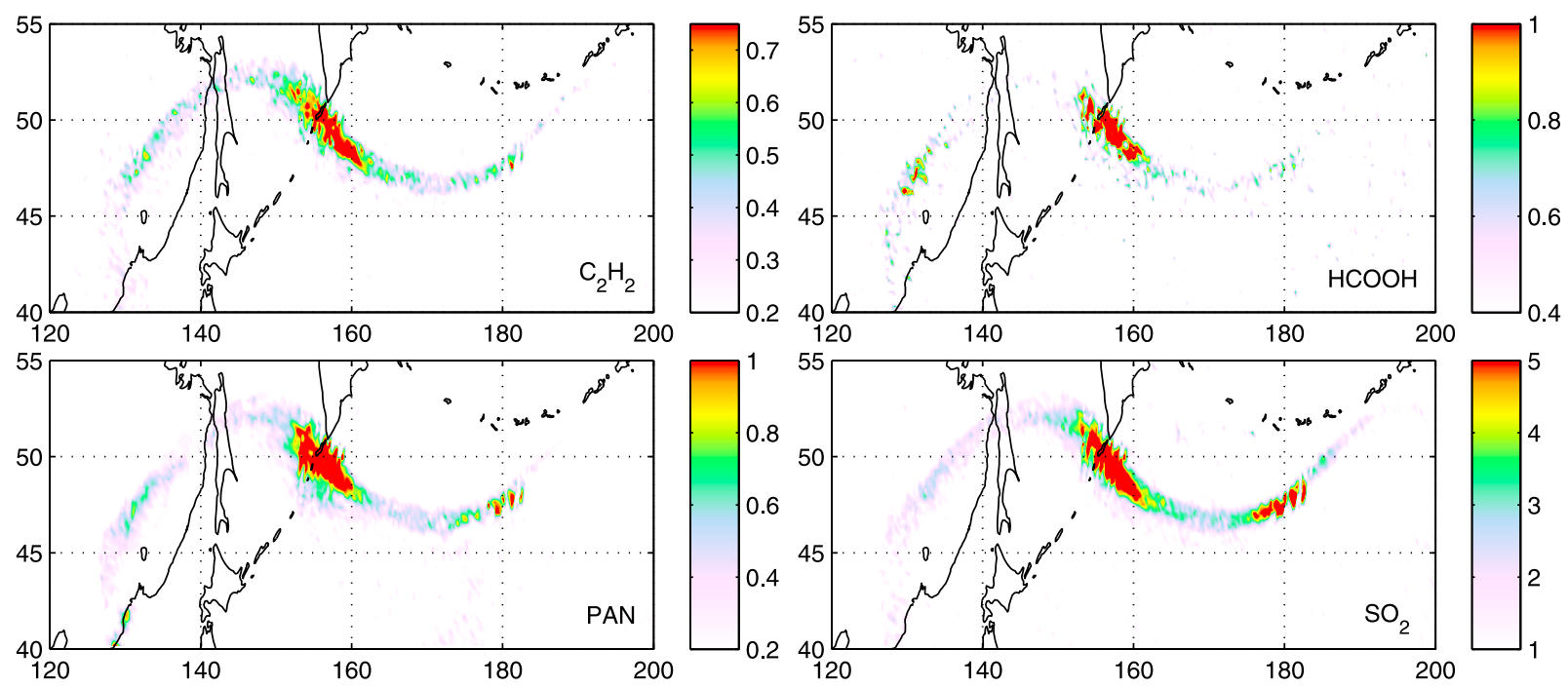

Figure 2. Example retrievals on 8 November 2011, $\mathrm{PM}$ of $\mathrm{C}_{2} \mathrm{H}_{2}, \mathrm{SO}_{2}, \mathrm{PAN}$ and $\mathrm{HCOOH}$ in units $10^{16}$ molecules $/ \mathrm{cm}^{2}$. While the abundances of these species correlate well (see also Figure $\mathrm{S} 2$ in the auxiliary material), the shape and location of the plume match almost perfectly. It can also be noted that $\mathrm{HCOOH}$ is only barely detectable in parts of the plume.

[15] All four species: $\mathrm{PAN}, \mathrm{C}_{2} \mathrm{H}_{2}, \mathrm{CO}$ and $\mathrm{SO}_{2}$ correlated well with each other throughout the event, with correlation coefficients above 0.5 . Correlations with $\mathrm{HCOOH}$ and $\mathrm{CH}_{3} \mathrm{OH}$ were lower (in the range $0.2-0.5$ ). This is mostly due to the larger noise of their retrievals (see Figure 2). Formic acid and methanol are emitted biogenically, with production peaking in the growing season, but also by fires, combustion and other anthropogenic activities [Stavrakou et al., 2011]. The main sink of formic acid is wet deposition, and concentrations are hence strongly linked with rainfall [see, e.g., Zhang et al., 2011]. As there was no precipitation in the week building up to the event, it is not surprising that this species was observed here. Of all the observed species, methanol abundances have the slowest decrease rate from the third to the last overpass, see Table 1 (slower than $\mathrm{SO}_{2}$ or the long-lived $\mathrm{CO}$ ). Since dispersion of the plume is the same for all observed species, and since dispersion is the main reason for the observed decrease in $\mathrm{CO}$ abundances, the slower decrease of $\mathrm{CH}_{3} \mathrm{OH}$ is strongly suggestive for in-plume formation, probably related to the oxidation of volatile organic compounds.

[16] We have also carried out a comparison of our measured columns with MOZART-4, driven by NCEP/GFS meteorology (see http://www.acd.ucar.edu/acresp/forecast/ for the figures), in order to see how a state of the art global chemistry transport model deals with such an event of strong uplift and long range transport. From the CO maps, outflow to the Pacific is obvious on the 8th of November. Transport is much slower though, as by the 11th the plume is still modeled over the Western Pacific, because of an underestimation of uplift and altitude. This is not surprising as modeling uplift and subsequent circulation through moist adiabatic storms is highly non-trivial. To assess the chemistry modeling of the build up, our measured columns have been compared with maximum measured columns below $800 \mathrm{hPa}$ in the morning of the 7th over the likely source area. Modeled columns agree well for $\mathrm{CO}, \mathrm{C}_{2} \mathrm{H}_{2}$ and $\mathrm{SO}_{2}$ but are underestimated for formic acid and PAN (almost a factor two) and especially methanol (a factor ten). These species are not surprisingly those which are least monitored (e.g. to our knowledge there has not been a single recent insitu campaign aimed at measuring wintertime PAN in North East Asia).

[17] This study provides a detailed analysis of one of the 24 identified events of major uplift and transport of anthropogenic sulfur dioxide. It is a first demonstration of how IASI is able to monitor outflow and chemistry of a range of primary and secondary pollutants. As retrieval techniques and instrumental characteristics of infrared sounders continue to improve, we expect it to be possible to monitor outflow of Asian pollution of a series of trace gases on a more regular basis, offering the modeling community unprecedented validation opportunities.

[18] Acknowledgments. IASI has been developed and built under the responsibility of the Centre National d'Etudes Spatiales (CNES, France). It is flown onboard the Metop satellites as part of the EUMETSAT Polar System. The IASI L1 data are received through the EUMETCast near real time data distribution service. L. Clarisse and P.-F. Coheur are Postdoctoral Researcher and Research Associate (Chercheur Qualifié), respectively, with F.R.S.-FNRS. C. Clerbaux is grateful to CNES for scientific collaboration and financial support. The research in Belgium was funded by the F.R.S.FNRS (M.I.S. nF.4511.08), the Belgian State Federal Office for Scientific, Technical and Cultural Affairs and the European Space Agency (ESAProdex arrangements C90-327). Financial support by the 'Actions de Recherche Concertées' (Communauté Française de Belgique) is also acknowledged.

[19] The Editor thanks two anonymous reviewers for their assistance in evaluating this paper.

\section{References}

Barrie, L. (1986), Arctic air pollution: An overview of current knowledge, Atmos. Environ., 20, 643-663.

Brice, K., J. Bottenheim, K. Anlauf, and H. Wiebe (1988), Long-term measurements of atmospheric peroxyacetylnitrate (PAN) at rural sites in Ontario and Nova Scotia: Seasonal variations and long-range transport, Tellus, Ser. B, 40, 408-425.

Chin, M., and D. Jacob (1996), Anthropogenic and natural contributions to tropospheric sulfate: A global model analysis, J. Geophys. Res., 101, $18,691-18,699$.

Chin, M., T. Diehl, P. Ginoux, and W. Malm (2007), Intercontinental transport of pollution and dust aerosols: Implications for regional air quality, Atmos. Chem. Phys., 7, 5501-5517, doi:10.5194/acp-7-5501-2007.

Clarisse, L., P. F. Coheur, A. J. Prata, D. Hurtmans, A. Razavi, T. Phulpin, J. Hadji-Lazaro, and C. Clerbaux (2008), Tracking and quantifying 
volcanic $\mathrm{SO}_{2}$ with IASI, the September 2007 eruption at Jebel at Tair, Atmos. Chem. Phys., 8, 7723-7734.

Clarisse, L., Y. R'Honi, P.-F. Coheur, D. Hurtmans, and C. Clerbaux (2011), Thermal infrared nadir observations of 24 atmospheric gases, Geophys. Res. Lett., 38, L10802, doi:10.1029/2011GL047271.

Clerbaux, C., et al. (2009), Monitoring of atmospheric composition using the thermal infrared IASI/MetOp sounder, Atmos. Chem. Phys., 9, 6041-6054.

Coheur, P.-F., B. Barret, S. Turquety, D. Hurtmans, J. Hadji-Lazaro, and C. Clerbaux (2005), Retrieval and characterization of ozone vertical profiles from a thermal infrared nadir sounder, J. Geophys. Res., 110, D24303, doi:10.1029/2005JD005845.

Coheur, P.-F., L. Clarisse, S. Turquety, D. Hurtmans, and C. Clerbaux (2009), IASI measurements of reactive trace species in biomass burning plumes, Atmos. Chem. Phys., 9, 5655-5667.

Di Pierro, M., L. Jaegle, and T. L. Anderson (2011), Satellite observations of aerosol transport from East Asia to the Arctic: Three case studies, Atmos. Chem. Phys., 11, 2225-2243, doi:10.5194/acp-11-2225-2011.

Fiedler, V., R. Nau, S. Ludmann, F. Arnold, H. Schlager, and A. Stohl (2009), East Asian $\mathrm{so}_{2}$ pollution plume over Europe-Part 1: Airborne trace gas measurements and source identification by particle dispersion model simulations, Atmos. Chem. Phys., 9, 4717-4728, doi:10.5194/ acp-9-4717-2009.

Gao, H., J. Chen, B. Wang, S.-C. Tan, C. M. Lee, X. Yao, H. Yan, and J. Shi (2011), A study of air pollution of city clusters, Atmos. Environ., 45, 3069-3077, doi:10.1016/j.atmosenv.2011.03.018.

George, M., et al. (2009), Carbon monoxide distributions from the IASI/ METOP mission: Evaluation with other space-borne remote sensors, Atmos. Chem. Phys., 9, 8317-8330, doi:10.5194/acp-9-8317-2009.

Heald, C., et al. (2003), Asian outflow and trans-Pacific transport of carbon monoxide and ozone pollution: An integrated satellite, aircraft, and model perspective, J. Geophys. Res., 108(D24), 4804, doi:10.1029/ 2003JD003507.

Jaffe, D., et al. (1999), Transport of Asian air pollution to North America, Geophys. Res. Lett., 26, 711-714.

Karagulian, F., L. Clarisse, C. Clerbaux, A. J. Prata, D. Hurtmans, and P. F. Coheur (2010), Detection of volcanic $\mathrm{SO}_{2}$, ash and $\mathrm{H}_{2} \mathrm{SO}_{4}$ using the IASI sounder, J. Geophys. Res., 115, D00L02, doi:10.1029/ 2009JD012786.

Kritz, M., J.-C. L. Roulley, and E. Danielsen (1990), The China clipper fast advective transport of radon-rich air from the Asian boundary layer to the upper troposphere near California, Tellus, Ser. B, 42, 46-61, doi:10.1034/j.1600-0889.1990.00007.x.

Law, K. S., and A. Stohl (2007), Arctic air pollution: Origins and impacts, Science, 315(5818), 1537-1540, doi:10.1126/science.1137695.

Lee, C., R. V. Martin, A. van Donkelaar, H. Lee, R. R. Dickerson, J. C. Hains, N. Krotkov, A. Richter, K. Vinnikov, and J. J. Schwab (2011), $\mathrm{SO}_{2}$ emissions and lifetimes: Estimates from inverse modeling using in situ and global, space-based (SCIAMACHY and OMI) observations, J. Geophys. Res., 116, D06304, doi:10.1029/2010JD014758.

Liang, Q., L. Jaegle, D. Jaffe, P. Weiss-Penzias, A. Heckman, and J. Snow (2004), Long-range transport of Asian pollution to the northeast Pacific: Seasonal variations and transport pathways of carbon monoxide, J. Geophys. Res., 109, D23S07, doi:10.1029/2003JD004402.

Liu, H., D. Jacob, I. Bey, R. Yantosca, B. Duncan, and G. Sachse (2003), Transport pathways for Asian pollution outflow over the Pacific: Interannual and seasonal variations, J. Geophys. Res., 108(D20), 8786, doi:10.1029/2002JD003102.

Russo, R. S., et al. (2003), Chemical composition of Asian continental outflow over the western Pacific: Results from Transport and Chemical
Evolution over the Pacific (TRACE-P), J. Geophys. Res., 108(D20), 8804, doi:10.1029/2002JD003184.

Stavrakou, T., A. Guenther, A. Razavi, L. Clarisse, C. Clerbaux, P.-F. Coheur, D. Hurtmans, F. Karagulian, M. De Mazière, C. Vigouroux, et al. (2011), First space-based derivation of the global atmospheric methanol emission fluxes, Atmos. Chem. Phys., 11, 4873-4898, doi:10.5194/ acp-11-4873-2011.

Stohl, A. (2001), A 1-year Lagrangian "climatology" of airstreams in the Northern Hemisphere troposphere and lowermost stratosphere, J. Geophys. Res., 106, 7263-7279.

Stohl, A., S. Eckhardt, C. Forster, P. James, and N. Spichtinger (2002), On the pathways and timescales of intercontinental air pollution transport, J. Geophys. Res., 107(D23), 4684, doi:10.1029/2001JD001396.

Streets, D., et al. (2003), An inventory of gaseous and primary aerosol emissions in Asia in the year 2000, J. Geophys. Res., 108(D21), 8809, doi:10.1029/2002JD003093.

Talbot, R., et al. (2003), Reactive nitrogen in Asian continental outflow over the western Pacific: Results from the NASA Transport and Chemical Evolution over the Pacific (TRACE-P) airborne mission, J. Geophys. Res., 108(D20), 8803, doi:10.1029/2002JD003129.

Tsalkani, N., P. Perros, and G. Toupance (1987), High PAN concentrations during nonsummer periods: A study of two episodes in Creteil (Paris), France, J. Atmos. Chem., 5, 291-299.

Turquety, S., et al. (2008), CO emission and export from Asia: An analysis combining complementary satellite measurements (MOPITT, SCIAMACHY and ACE-FTS) with global modeling, Atmos. Chem. Phys., 8, 5187-5204, doi:10.5194/acp-8-5187-2008.

Walker, J. C., A. Dudhia, and E. Carboni (2011), An effective method for the detection of trace species demonstrated using the MetOp Infrared Atmospheric Sounding Interferometer, Atmos. Meas. Tech., 4, 1567-1580, doi:10.5194/amt-4-1567-2011.

Winker, D. M., M. A. Vaughan, A. Omar, Y. Hu, K. A. Powell, Z. Liu, W. H. Hunt, and S. A. Young (2009), Overview of the CALIPSO mission and CALIOP data processing algorithms, J. Atmos. Oceanic Technol., 26(11), 2310-2323.

Xiao, Y., D. J. Jacob, and S. Turquety (2007), Atmospheric acetylene and its relationship with $\mathrm{CO}$ as an indicator of air mass age, J. Geophys. Res., 112, D12305, doi:10.1029/2006JD008268.

Yienger, J., M. Galanter, T. Holloway, M. Phadnis, S. Guttikunda, G. Carmichael, W. Moxim, and H. Levy (2000), The episodic nature of air pollution transport from Asia to North America, J. Geophys. Res., 105, 26,931-26,945.

Yu, H., L. A. Remer, M. Chin, H. Bian, R. G. Kleidman, and T. Diehl (2008), A satellite-based assessment of transpacific transport of pollution aerosol, J. Geophys. Res., 113, D14S12, doi:10.1029/2007JD009349.

Zhang, L., et al. (2006), Ozone-CO correlations determined by the TES satellite instrument in continental outflow regions, Geophys. Res. Lett., 33, L18804, doi:10.1029/2006GL026399.

Zhang, Y., X. Lee, and F. Cao (2011), Chemical characteristics and sources of organic acids in precipitation at a semi-urban site in Southwest China, Atmos. Environ., 45, 413-419.

L. Clarisse, C. Clerbaux, P.-F. Coheur, D. Hurtmans, and Y. Ngadi, Spectroscopie de l'Atmosphère, Service de Chimie Quantique et Photophysique, Université Libre de Bruxelles, B-1050 Brussels, Belgium. (lclariss@ulb.ac.be)

L. Emmons, National Center for Atmospheric Research, PO Box 3000, 1850 Table Mesa Dr., Boulder, CO 80307, USA.

M. Fromm, U.S. Naval Research Laboratory, 4555 Overlook Ave. SW, Washington, DC 20375, USA. 